\title{
Distributions and assemblages of larval fish in the East China Sea during the northeasterly and southwesterly monsoon seasons of 2008
}

\author{
W. Y. Chen ${ }^{1,2}$, M. A. Lee ${ }^{2,3}$, K. W. Lan ${ }^{2}$, and G. C. Gong ${ }^{3,4}$ \\ ${ }^{1}$ Coastal and Offshore Resources Research Center, Taiwan Fishery Research Institute, Kaohsiung, Taiwan \\ ${ }^{2}$ Department of Environmental Biology and Fisheries Science, National Taiwan Ocean University, Keelung, Taiwan \\ ${ }^{3}$ Center of Excellence for the Oceans, National Taiwan Ocean University, Keelung, Taiwan \\ ${ }^{4}$ Taiwan Ocean Research Institute, National Applied Research Laboratories, Taiwan
}

Correspondence to: M. A. Lee (malee@ mail.ntou.edu.tw)

Received: 5 March 2013 - Published in Biogeosciences Discuss.: 22 April 2013

Revised: 3 December 2013 - Accepted: 17 December 2013 - Published: 3 February 2014

\begin{abstract}
A total of 8459 larval fish were collected from the southern East China Sea during the winter northeasterly monsoon season and the summer southwesterly monsoon season of 2008. The larvae comprised 184 species belonging to 105 families and 162 genera. The abundance in terms of CPUE (number of individuals $/ 1000 \mathrm{~m}^{3}$ ) of the larvae was approximately 6 times higher during the southwesterly monsoon season than it was during the northeasterly monsoon season. The primary environmental factors affecting the larval abundance were water temperature during the northeasterly monsoon season, and food availability during the southwesterly monsoon season. Three larval fish assemblages were recognized: inshore assemblage, offshore assemblage, and summer coastal assemblage. The distribution and species composition of the larvae in the assemblages reflected the hydrographic conditions and water currents resulting from the seasonal monsoons.
\end{abstract}

\section{Introduction}

The East China Sea (ECS) is one of the largest marginal seas in the world. The ECS is bordered by mainland China, Taiwan, the Japanese archipelago, and the Korean peninsula. The hydrographic systems in the continental shelf of the ECS are known to be influenced by the southward China Coastal Current and water from the Yellow Sea during the northeasterly monsoon season, and by the northward Kuroshio Current and the Taiwan Strait Current during the southwesterly monsoon season (Katoh et al., 2000; Gong et al., 2003; Yang et al., 2011, 2012). Freshwater discharges from the Yangtze River also affect the hydrographic system of the ECS during summer (Gong et al., 1996).

Ichthyoplankton are meroplankton, a planktonic stage that is highly sensitive to environmental changes. The spatial distribution of ichthyoplankton assemblages is closely related to oceanic hydrographic features (Okazaki et al., 2002; Okazaki and Nakata, 2007; Lo et al., 2010). These features act as mechanisms of enrichment, concentration, and retention of larval fish, affecting their survival and production (Okazaki et al., 2002; Hsieh et al., 2011). This biological-physical relationship has been observed in estuarine systems (Queiroga et al., 1997; DiBacco et al., 2001), shelf-break fronts (Hsieh et al., 2007; Chen et al., 2012), and upwelling areas (Vargas and Castro, 2001; Yannicelli et al., 2006).

Many studies have been conducted on the changes in the structure of larval fish assemblages in relation to hydrographic conditions, including current transportation (Sassa et al., 2006), seasonal changes (Hsieh et al., 2011), and food availability and competition (Sassa et al., 2008). For the ECS, such studies have been made on a shelf-break area (Okazaki and Nakata, 2007), and the waters around Taiwan (Hsieh et al., 2010). The shelf-break studies have focused on the effect of the Kuroshio frontal eddy on larval fish during summer, and the studies of waters around Taiwan have focused on the effect of the South China Sea Surface Current and the Kuroshio Current around Taiwan on larval fish, also during summer. Recently, there has been increased attention focused on the effects of monsoon systems on marine environments, particularly on the circulation pattern in the Taiwan Strait (Lo 


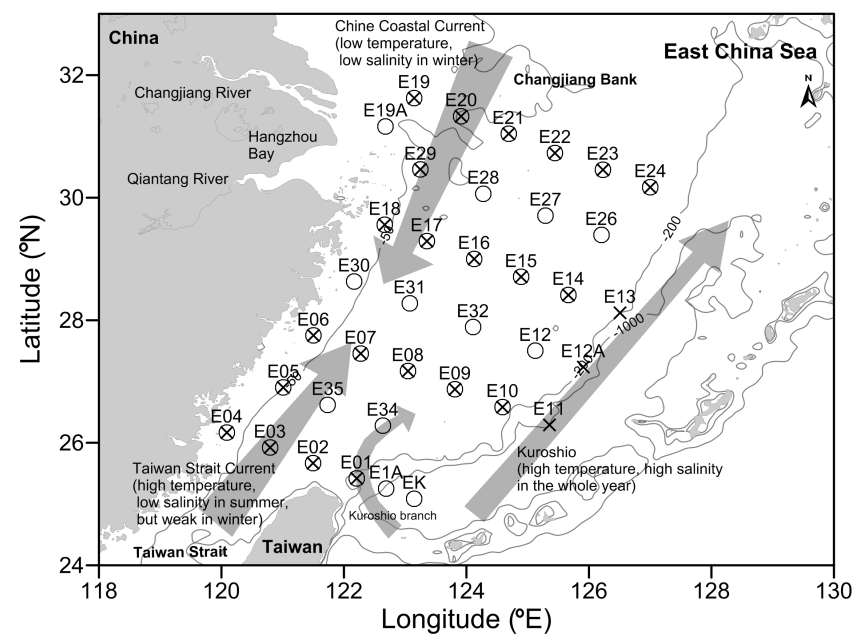

Fig. 1. Locations of the larval fish sampling stations in the northeasterly monsoon season (crosses), the southwesterly monsoon season (open circles) and both seasons (open circles with cross) in the ECS, 2008.

et al., 2010; Hsieh et al., 2010, 2011, 2012). The spatiotemporal difference in larval fish assemblages has been studied in relation to local hydrographic features between the different monsoon seasons in the northwest Pacific Ocean (Hsieh et al., 2011, 2012). The previous studies have mainly investigated larval fish assemblages in the waters around Taiwan; however, few studies have been conducted over the entire area of the East China Sea.

From 1997 to 2013, we conducted the project "Long-term Observation and Research of the East China Sea" (LORECS) in order to determine the biogeochemical cycle and main plankton loop and subsequently assess the impacts of the reduction in the Yangtze River discharges - caused by the construction of Three Gorges Dam - on marine environments (Gong et al., 2007). This study was part of the LORECS, but the influence of changes in the artificial environment was difficult to display in the annual data. For this reason, this survey focused on changes during different monsoon seasons. We investigated the species composition, spatial distributions of fish larval assemblages, and abundance of larval fish in the ECS. In addition, we compared the larval fish in the two distinct monsoon seasons, and their different relationships to environmental factors on the continental shelf of the East China Sea. Moreover, we determined the factors responsible for larval abundance.

\section{Materials and methods}

\subsection{Data collection}

At 16 stations, larval fish were collected on-board the Ocean Research I vessel in January and July 2008 (Fig. 1), using an Ocean Research Institute (ORI) net with a mouth diame- ter of $1.6 \mathrm{~m}$ and stretch mesh size of $0.33 \mathrm{~mm}$. The net was towed obliquely from a depth of $200 \mathrm{~m}$ to the surface at deep stations (depths $>200 \mathrm{~m}$ ), or from $10 \mathrm{~m}$ above the bottom to the surface at shallow stations $(<200 \mathrm{~m})$. The volume of water filtered was calculated using a flow meter attached to the center of the net. The samples were fixed in $5 \%$ buffered formalin seawater. In the laboratory, ichthyoplankton were sorted from the collection, and identified to the lowest taxonomic level possible, according to the atlas of Okiyam (1988) and Leis and Carson-Ewart (2000). Larval fish and zooplankton abundance was calculated and standardized as CPUE (number of individuals $/ 1000 \mathrm{~m}^{3}$ ) and zooplankton $\mathrm{Wt}$ $\left(\mathrm{g} 1000 \mathrm{~m}^{-3}\right)$. Hydrographic data and water samples for measuring nutrients, chlorophyll, and primary productivity were taken using a CTD (SBE9/11 plus, Seabird Inc., USA) and rosette (model 1015, General Oceanics Inc., USA). Nutrient samples were collected using Teflon-coated Go-Flo bottles (20 L, General Oceanics Inc., USA) mounted on a rosette sampler, and stored in liquid nitrogen until ready for analysis. Nutrients (nitrate, phosphate, and silicate), chlorophyll $a$, and primary productivity were determined as previously described (Chen et al., 2009; Gong et al., 2011).

Mesoscale oceanographic conditions of the ECS were obtained from the satellite images and Hybrid Coordinate Ocean Model (HYCOM) data. Sea surface temperature (SST) images were obtained from the National Oceanic and Atmospheric Administration/Advanced Very High Resolution Radiometer (NOAA/AVHRR) sensors (Lee et al., 2005). The HYCOM ocean surface currents with $1 / 12^{\circ}$ spatial resolution were downloaded from the OPeNDAP (Open-source Project for a Network Data Access Protocol) ocean database (http://opendap.org/ml-toolbox; Cornillon et al., 2009).

\subsection{Data analysis}

CPUE is used for describing and comparing larval distributions between geographical regions. Zooplankton $\mathrm{Wt}$ is used for describing zooplankton abundance. Chlorophyll $a$ concentration and primary productivity (PP, $\mathrm{mgC} / \mathrm{m} 2 \mathrm{~d}$ ) are used for describing the phytoplankton biomass and productivity. Therefore, in this study, we used the zooplankton $\mathrm{Wt}$, chlorophyll $a$ concentration, and primary productivity as indicators of the amount of food for larval fish.

The Mann-Whitney $U$ test was conducted to determine significant differences between the CPUEs of the two monsoon seasons. The Kruskal-Wallis test was performed to compare the CPUEs of the three assemblages. Dunn's test was applied for post-hoc comparisons. Chi-square analysis was used to determine the difference between the species composition of the three assemblages. CPUEs were normalized using a logarithmic function $[\ln (x+1)]$ transformation. We used cluster analysis to examine the community structure of the larvae for each monsoon season. Cluster analysis with normalized Euclidean distances was conducted to measure levels of similarity in species composition among 


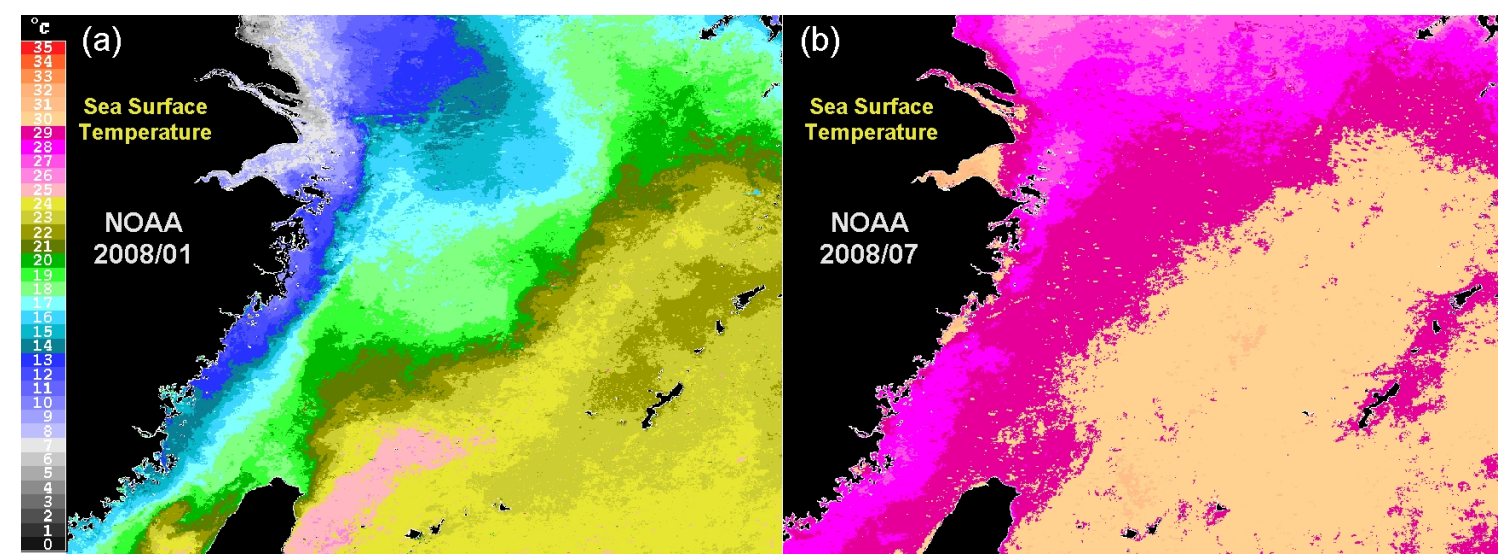

Fig. 2. Satellite images of monthly mean sea surface temperature in the ECS in the months of January and July 2008.
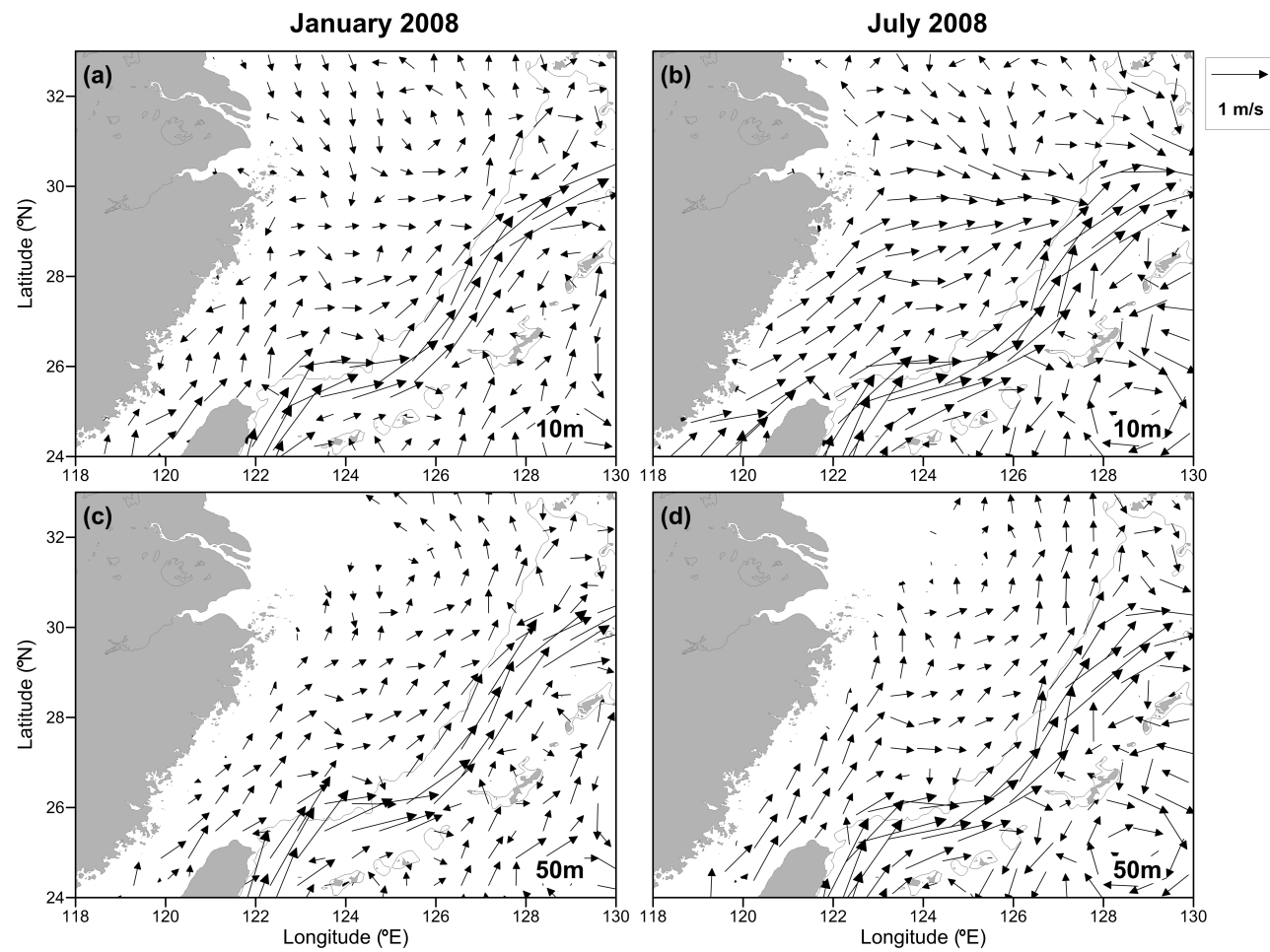

Fig. 3. Current conditions (length of arrow, current speed with a scale of $1 \mathrm{~m} \mathrm{~s}^{-1}$; arrow direction, current direction) at the depths of $10 \mathrm{~m}$ $((\mathbf{a}), \mathbf{b})$ and $50 \mathrm{~m}(\mathbf{c}, \mathbf{d})$ in the ECS derived from the OPeNDAP ocean database, January and July 2008.

the sampling stations; Ward's method was used to illustrate their relationships in a dendrogram. Cluster analysis was processed using the STATISTICA 8 statistical software package.

Pearson's correlation analyses were conducted to determine the relationship between CPUEs and SST, primary production, and zooplankton wet weight. Nonlinear relationships between dominant taxa and environmental variables were analyzed using the canonical correlation analysis (CCA), a statistical visualization method (ter Braak, 1994).

\section{Results}

\subsection{Hydrographic conditions}

Satellite maps of temperatures and current directions in January and July 2008 showed the mesoscale environmental features in the ECS (Figs. 2 and 3). During winter, the strong northeasterly monsoon wind drove over the near-surface current $(10 \mathrm{~m})$ along the coast of China, flowing southward, whereas the northeasterly monsoon wind from the northwest, off Taiwan, continued to flow toward the north. During 

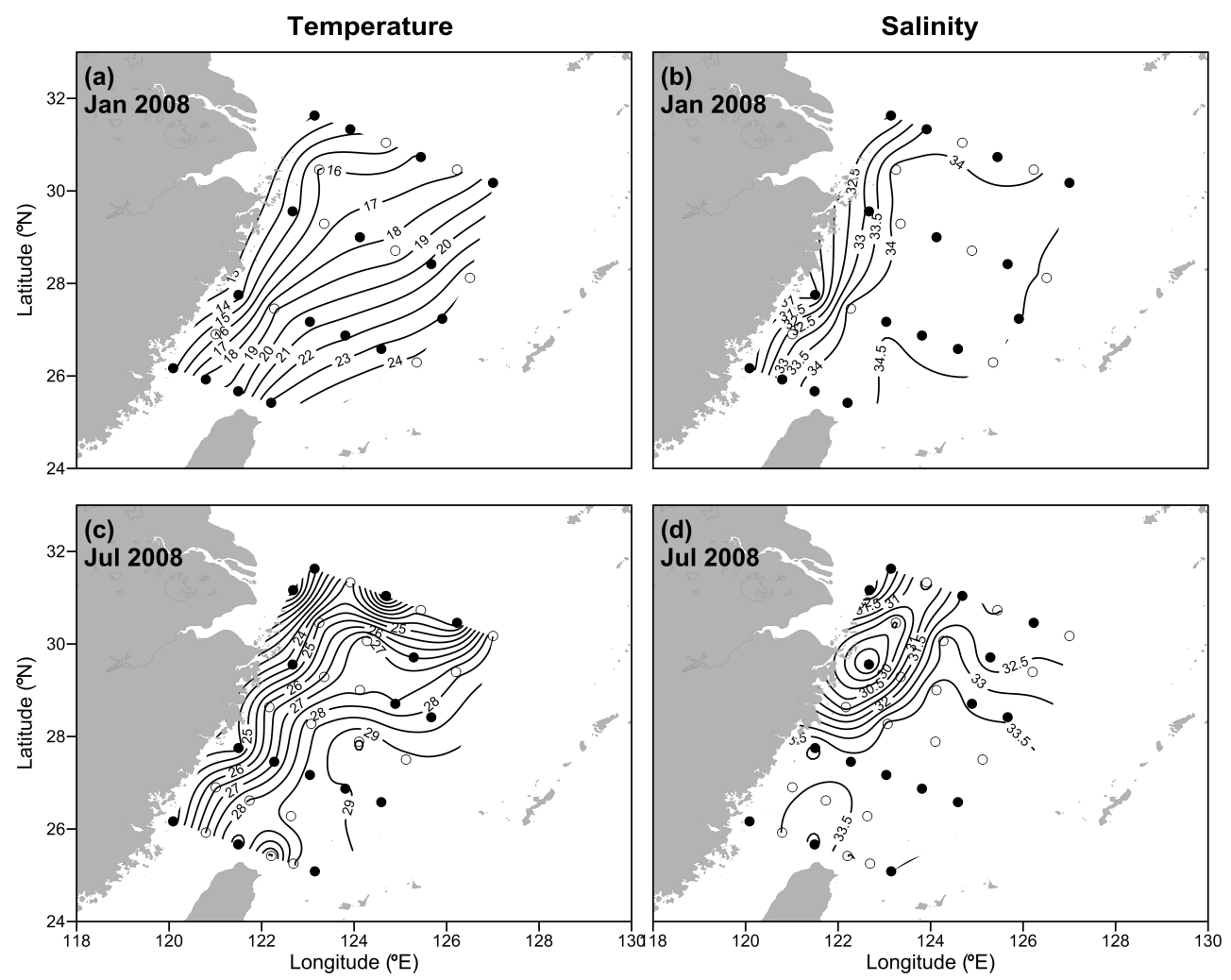

Fig. 4. Spatial distributions of temperature and salinity isopleths at the depths of $10 \mathrm{~m}$ in the ECS, 2008 (open circles, stations with CTD data only; solid circles, stations with both CTD data and the data from the fish larval sampling).

Table 1. Results of Mann-Whitney $U$ test for seasonal and diurnal differences in larval fish abundance (CPUE) in the ECS, 2008.

\begin{tabular}{lccc}
\hline Periods & & $\begin{array}{c}\text { Number } \\
\text { of station }\end{array}$ & $p$ value \\
\hline $\begin{array}{l}\text { northeasterly monsoon } \\
\text { southwesterly monsoon }\end{array}$ & 16 & 0.0008 \\
\hline northeasterly & day & 8 & 0.9164 \\
& night & 8 & \\
\hline \multirow{2}{*}{ southwesterly } & day & 7 & 0.1248 \\
& night & 9 & \\
\hline
\end{tabular}

this time, the current in the lower layer along the coast of China continued flowing northward (in an opposite direction to that in the near-surface), because the influence of wind stress became weak at this depth. During summertime, the southwesterly wind enhanced the northward current in the Taiwan Strait, resulting in an eastward current on the shelf along $30^{\circ} \mathrm{N}$, because of a north-south convergence in this region. Nevertheless, at a $50 \mathrm{~m}$ depth, this eastward current was absent. To the east of Taiwan, the Kuroshio Current seemed to be strengthened and diminished by the summer and winter monsoon, respectively.
The SST and salinity distributions at a depth of $10 \mathrm{~m}$ in January and July 2008 are shown in Fig. 4. In general, the temperature and salinity at the stations adjacent to the coast of China were low. During the winter northeasterly monsoon season, the SSTs ranged between 12.1 and $24.3^{\circ} \mathrm{C}$, and salinities ranged between 30.8 and 34.6 psu. During the southwesterly monsoon season, the temperatures were between $19.6^{\circ} \mathrm{C}$ and $29.6^{\circ} \mathrm{C}$, higher than those during the northeasterly monsoon season. Salinities varied between 28.0 and 34.2 psu. Salinities lower than 31 psu (Gong et al., 1996) were observed only at the Yangtze River estuary during the southwesterly monsoon season.

\subsection{Abundance and composition of larval fish in relation to environments}

The CPUEs showed a significant difference between the northeasterly and southwesterly monsoon seasons (MannWhitney $U$ test, $p<.05$ ), but not between day and night in each of the two seasons (Table 1). Because we tested for night-day differences for each monsoon season and did not observe significant differences, we combined all samples. A total of 8459 fish larvae were collected. They comprised 184 species belonging to 105 families and 162 genera, with a total CPUE of $15534 / 1000 \mathrm{~m}^{3}$. The spatial distribution of larval abundance, expressed as CPUE, is 


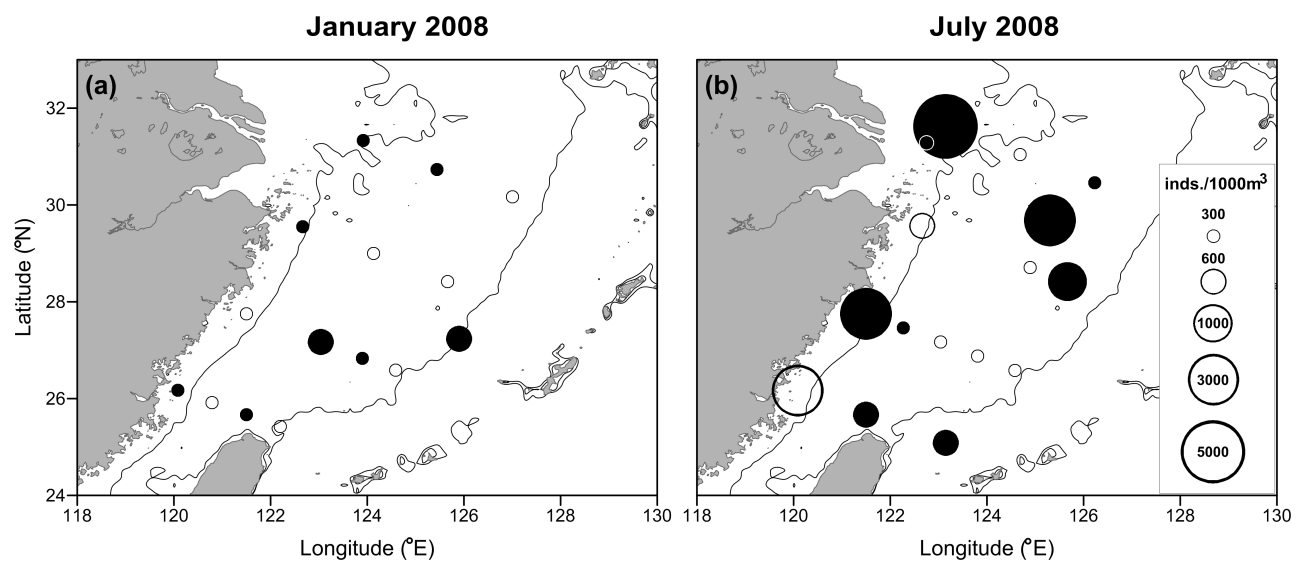

Fig. 5. CPUEs (ind. $/ 1000 \mathrm{~m}^{3}$ ) of larval fish in the northeasterly monsoon season (a) and the southwesterly monsoon season (b) ( open circles, daytime sampling; solid circles, nighttime sampling).

shown in Fig. 5. The average CPUE was 143 ind./1000 $\mathrm{m}^{3}$ during the northeasterly monsoon season, approximately six times lower than that during the southwesterly monsoon season ( 828 ind. $/ 1000 \mathrm{~m}^{3}$ ). The maximum CPUEs were 502 ind. $/ 1000 \mathrm{~m}^{3}$ at station E8 during the northeasterly monsoon season, and 4061 ind. $/ 1000 \mathrm{~m}^{3}$ at station E19 during the southwesterly monsoon season (Fig. 5).

Figure 6 shows the relationships between CPUEs and environmental variables (SST, primary production, and zooplankton wet weight). During the northeasterly monsoon season, CPUEs were significantly and positively correlated $(r=0.61, p<0.05)$ only with the SST. There was no significant correlation between CPUE and zooplankton $\mathrm{Wt}(r=$ $-0.06, p>0.05$; Fig. $6 c$ ) when station E20 - where a shrimp bloom occurred - was excluded. During the southwesterly monsoon season, a significant, positive correlation was observed only between CPUEs and primary production $(r=$ $0.64, p<0.05)$. A positive correlation was also observed between CPUEs and zooplankton Wt $(r=0.82, p<0.05)$ (Fig. 6f) when station E19A - where the Yangtze River discharges occurred - was excluded. The dominant species of larval fish $(>1 \%)$ are shown in Table 2. During the northeasterly monsoon season, the dominant species were Valamugil sp., Sigmops gracilis, and scorpaenid larvae. When their numbers were combined, the combined average CPUE was 795 ind. $/ 1000 \mathrm{~m}^{3}$, representing $34.48 \%$ of the total larval fish sample. During the southwesterly monsoon season, gobiid type 2, Saurida spp., and Engraulis japonicus were the dominant taxa, accounting for 6084 ind. $/ 1000 \mathrm{~m}^{3}$, which represented $45.92 \%$ of the total sample.

The ordination diagrams of the canonical correlation analysis (CCA) of the CPUEs of the dominant larval fish taxa and environment variables are shown in Fig. 7. During the northeasterly monsoon period, the CPUE of each $S$. gracilis was positively correlated with SST and sea surface salinity, but negatively correlated with nutrients, dissolved oxygen (DO), and zooplankton $\mathrm{Wt}$, which was the opposite of the
CPUE of scorpaenid larvae (Fig. 7a). During the southwesterly monsoon season, the CPUE of Engraulis japonicus was positively correlated with primary production. Saurida spp. and gobiid type 1 larvae were negatively correlated with sea surface salinity, which was the opposite of the CPUE of gobiid type 2 (Fig. 7b).

\subsection{Assemblages and biodiversity of larval fish}

The dendrogram and geographic locations of the larval fish communities were analyzed using cluster analysis for the two monsoons seasons (Fig. 8). In the dendrogram, three assemblages were recognized based on the station association and spatial distribution pattern of the species. These assemblages were the inshore assemblage, offshore assemblage, and summer coastal assemblage. The latter occurred only during the southwesterly monsoon season. The dominant species of each of the assemblages, with ecological information of the species at the adult stage in the two monsoon seasons, are shown in Table 3. Larval CPUEs showed significant differences among the three assemblages (KruskalWallis test, $p<0.05$, Table 4$)$. The species composition of the three assemblages differed (chi-square test, $p<0.05$ ).

The inshore assemblage was observed at 11 stations during the northeasterly monsoon season and at three stations during the southwesterly monsoon season (Fig. 8). This assemblage was located in the area with a low SST and sea surface salinity (Fig. 4), with an average CPUE of 68 ind. $/ 1000 \mathrm{~m}^{3}$ during the northeasterly monsoon season and $168 \mathrm{ind} . / 1000 \mathrm{~m}^{3}$ during the southwesterly monsoon season (Table 3). Its abundance was the lowest of the three assemblages. The most dominant species of larvae in the inshore assemblage was the scorpaenid larvae, which accounted for $26.45 \%$ of species during the northeasterly monsoon season, and $20.18 \%$ of species during the southwesterly monsoon season (Table 3 ). The offshore assemblage was observed at five stations during the northeasterly monsoon 
(a)
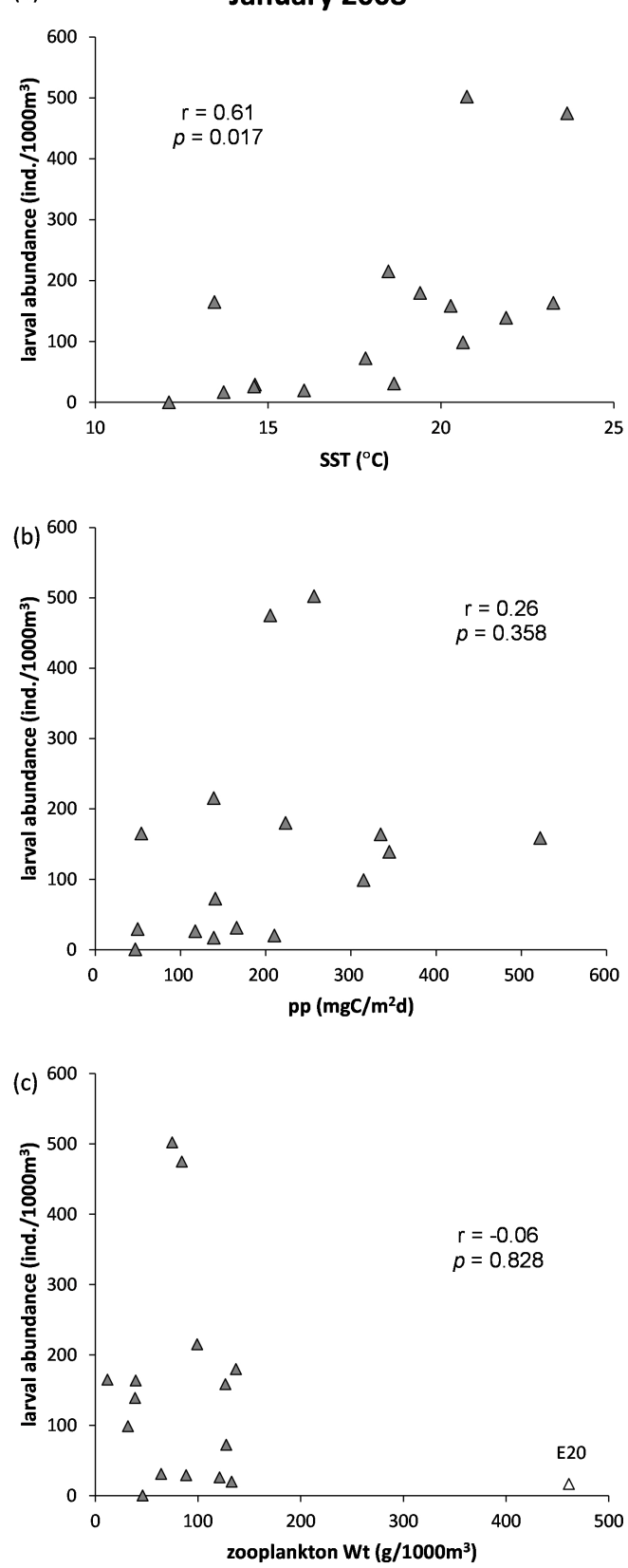

(d) July 2008
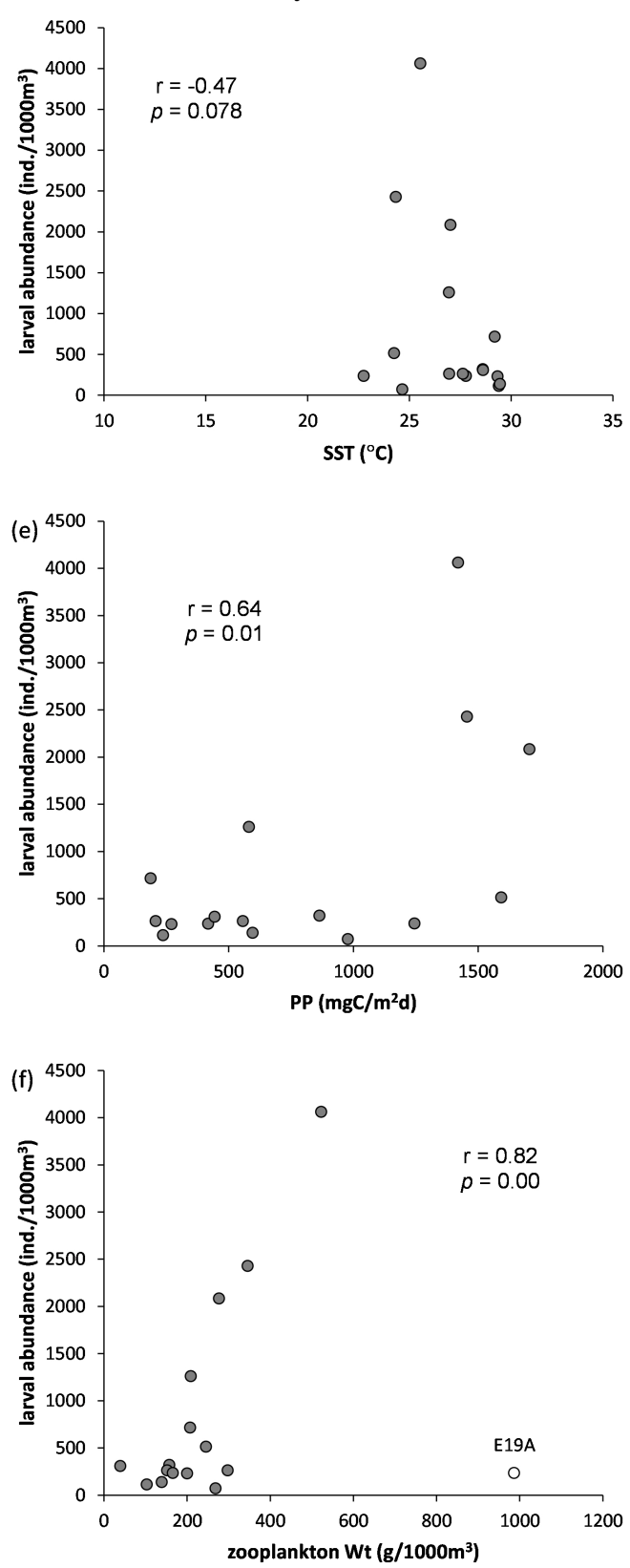

Fig. 6. Relationships between CPUE of larval fish and each of the environmental variables - sea surface temperature, primary production, and zooplankton wet weight.

season and at eight stations during the southwesterly monsoon season, in the offshore region (Fig. 8) with a high SST and sea surface salinity (Fig. 4). The average CPUE of this assemblage was 286 ind. $/ 1000 \mathrm{~m}^{3}$ during the northeasterly monsoon season and 289 ind. $/ 1000 \mathrm{~m}^{3}$ during the southwesterly monsoon season. These values were two to four times higher than those of the inshore assemblages for both seasons (Table 3). The most dominant species were Valamugil sp. during the northeasterly monsoon season and Tra- chinocephalus myops during the southwesterly monsoon season. Valamugil sp. had a CPUE of 323 ind./1000 $\mathrm{m}^{3}$, representing $22.61 \%$ of the total offshore assemblage sample, whereas T. myops had $295 \mathrm{ins} . / 1000 \mathrm{~m}^{3}$, accounting for $12.79 \%$ of that sample.

Summer coastal assemblage occurred only at five stations at the $50 \mathrm{~m}$ isopleth along the south coast of China and at the mouth of the Yangtze River, during the southwesterly monsoon season (Fig. 8b). Its 
Table 2. Abundance (CPUE, number of individuals $/ 1000 \mathrm{~m}^{3}$ ) of dominant species of larval fish in the northeasterly and southwesterly monsoon seasons in the ECS, 2008.

\begin{tabular}{|c|c|c|c|c|c|}
\hline \multicolumn{3}{|c|}{ Northeasterly monsoon } & \multicolumn{3}{|c|}{ Southwesterly monsoon } \\
\hline Species & $\begin{array}{c}\text { CPUE } \\
\text { (ind. } / 1000 \mathrm{~m}^{3} \text { ) }\end{array}$ & $\%$ & Species & $\begin{array}{c}\text { CPUE } \\
\text { (ind. } / 1000 \mathrm{~m}^{3} \text { ) }\end{array}$ & $\%$ \\
\hline Valamugil sp. & 326 & 14.23 & Gobiidae type 2 & 2344 & 17.69 \\
\hline Sigmops gracilis & 239 & 10.46 & Saurida spp. & 2274 & 17.16 \\
\hline Scorpaenidae & 230 & 10.06 & Engraulis japonicus & 1466 & 11.07 \\
\hline Diaphus A group & 145 & 6.33 & Gobiidae type 1 & 1064 & 8.03 \\
\hline Diaphus B group & 113 & 4.95 & Bregmaceros spp. & 902 & 6.81 \\
\hline Callionymidae & 111 & 4.85 & Sciaenidae & 763 & 5.76 \\
\hline Gobiidae type 2 & 71 & 3.09 & Cynoglossus spp. & 714 & 5.39 \\
\hline Trachurus japonicus & 67 & 2.93 & Other Gobiidae species & 359 & 2.71 \\
\hline Other Gobiidae species & 62 & 2.71 & Apogontidae & 352 & 2.66 \\
\hline Bregmaceros spp. & 60 & 2.61 & Benthosema pterotum & 304 & 2.29 \\
\hline Myctophum asperum & 40 & 1.77 & Trachinocephalus myops & 295 & 2.23 \\
\hline Triglidae & 39 & 1.72 & Callionymidae & 235 & 1.77 \\
\hline Champsodon sp. & 35 & 1.51 & Leiognathidae & 170 & 1.29 \\
\hline Ceratoscopelus warmingii & 34 & 1.47 & Scorpaenidae & 146 & 1.1 \\
\hline Trichiurus lepturus & 33 & 1.43 & Auxis sp. & 136 & 1.03 \\
\hline Vinciguerria nimbaria & 29 & 1.25 & Others $(<1 \%, 170$ species $)$ & 1722 & 13 \\
\hline Scomber japonicus & 29 & 1.25 & Total & 13246 & 100 \\
\hline Teraponidae & 25 & 1.09 & Average & 828 & \\
\hline Scomber australasicus & 23 & 1.02 & & & \\
\hline Others $(<1 \%, 165$ species $)$ & 578 & 25.27 & & & \\
\hline Total & 2288 & 100 & & & \\
\hline Average & 143 & & & & \\
\hline
\end{tabular}

abundance was 10304 ind./1000 $\mathrm{m}^{3}$, higher than those of the other two assemblages (Table 3). The three dominant species were gobiid type 2 (2344 ind./1000 $\left.\mathrm{m}^{3}\right)$, Saurida larvae (2234 ind./1000 $\mathrm{m}^{3}$ ), and Engraulis japonicus (1378 ind./1000 $\mathrm{m}^{3}$ ) (Table 3). E. japonicus larvae were highly aggregated at stations E19 (446 ind./1000 $\mathrm{m}^{3}$ ) and E27 $\left(897\right.$ ind. $\left./ 1000 \mathrm{~m}^{3}\right)$, which were located at or near the Yangtze River estuary.

Figure 9 shows the ordination diagrams of the canonical correlation analysis (CCA), which were used to evaluate the relationship between assemblages and environmental variables. Inshore assemblage during the southwesterly monsoon season was positively correlated with SST but negatively correlated with DO, which was the opposite of the inshore assemblage of the northeasterly monsoon season (Fig. 9). Summer coastal assemblage showed a negative relationship with sea surface salinity and a positive relationship with nutrient and primary production. Offshore assemblage during the northeasterly monsoon season was negatively correlated with zooplankton wet weight.

\section{Discussion}

\subsection{Seasonal difference in oceanic currents}

The hydrography in the ECS was strongly influenced by the seasonal changes in the China Coastal Current, Taiwan Strait Current, and Kuroshio Branch Current. Even the boundary of the Kuroshio Current, having high temperature and salinity, was along the shelf break of the ECS during the two monsoon seasons (Figs. 2 and 3). During the northeasterly monsoon season, water temperature was low, with an obvious intensive thermal front. When the monsoon wind turned northeast, it made the China Coastal Current flow southwardly. It has been reported that that the cold China Coastal Current expands southward over the mid-shelf of the ECS, and interacts with the Kuroshio Branch Current to form thermal fronts along the $50 \mathrm{~m}$ isopleth (Fig. 2a) (Chang et al., 2008). The extension of the southward China Coastal Current along the coast of China disappeared during the southwesterly monsoon season (Fig. 2b).

The Kuroshio Branch Current and the Taiwan Strait Current concurrently intrude into the East China Sea, carrying warm water from the south during the southwesterly monsoon (Isobe, 2008). At the south of Changjiang River, these 
Table 3. The abundance (Abu.; i.e., CPUE, ind./1000 $\mathrm{m}^{3}$ ) and percentage contribution of dominant larval fish ( $\left.>80 \%\right)$ of three larval fish assemblages in the ECS, 2008 (NE, the northeasterly monsoon season; SW, the southwesterly monsoon season).

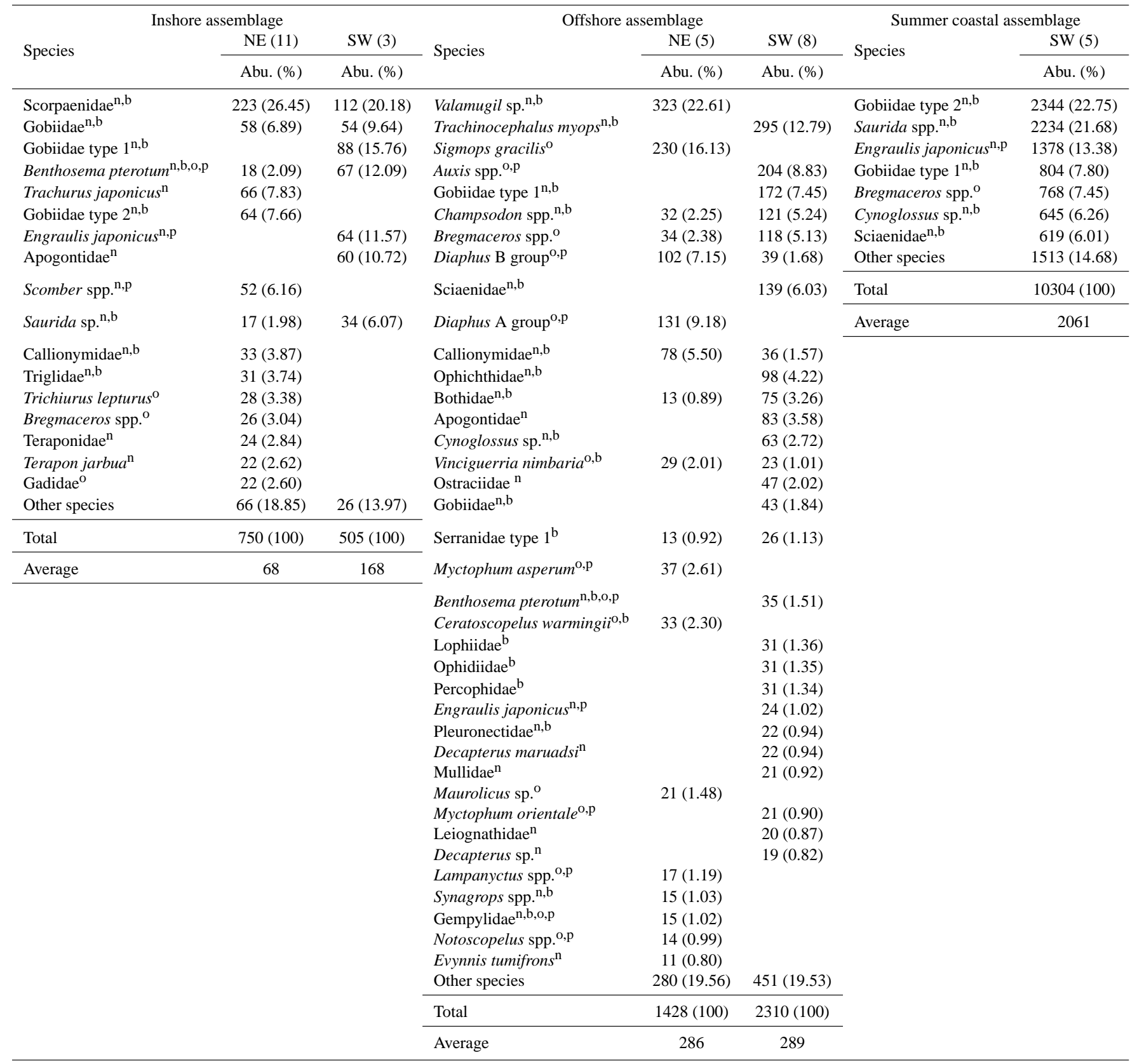

currents may block the southward flow of the China Coastal Current with cold water from the north. (Figs. 3b and 4). The intrusion of low-salinity water into the East China Sea has been described by Chang and Isobe (2003) and Gong et al. (2011), who suggested that the discharge of the Yangtze River into the sea extends far to the northeast, but is constrained by the Taiwan Strait Current during the southwesterly monsoon season.

\subsection{Abundance of larval fish in relation to environmental variables}

The major factors affecting larval abundance were temperature and food sources. In this study, the abundance of larval fish in the ECS during the northeasterly monsoon season was found to be much lower than that during the southwesterly monsoon season (Table 2); this is a similar result to that obtained by Hernandez et al. (2010). It is known that larval fish are abundant during the warm season (Meekan et al., 

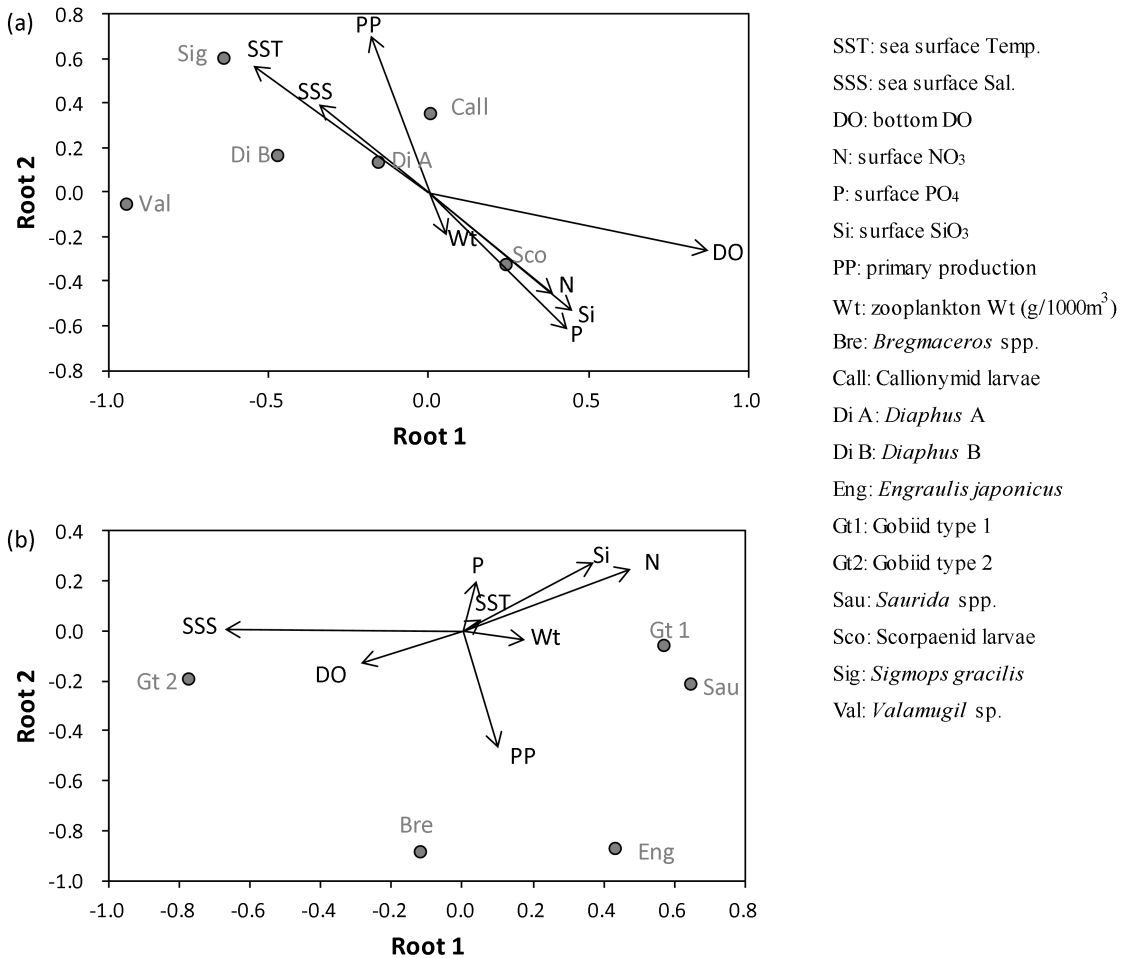

Fig. 7. Ordination diagram of canonical correlation analysis (CCA) showing the relationships between hydrographic factors and abundance of dominant larval fish taxa in the northeasterly monsoon season (a) and the southwesterly monsoon season (b).

Table 4. Results of the Kruskal-Wallis test and Dunn's test (post hoc comparisons) for CPUEs of three assemblages.

\begin{tabular}{cccc}
\hline $\begin{array}{c}\text { Inshore } \\
\text { assemblage (A) } \\
\text { Median (IQR) }\end{array}$ & $\begin{array}{c}\text { Offshore } \\
\text { assemblage (B) } \\
\text { Median (IQR) }\end{array}$ & $\begin{array}{c}\text { Summer coastal } \\
\text { assemblage (C) } \\
\text { Median (IQR) }\end{array}$ & $p$ \\
\hline $72^{\mathrm{a}}(153)$ & $235^{\mathrm{a}}(161)$ & $2085^{\mathrm{a}}(1169)$ & $<0.01^{*}$ \\
\hline IQR, Interquartile range. ${ }^{\mathrm{a}}$ A was the difference between B and C.
\end{tabular}

2003), and low temperatures $\left(<20^{\circ} \mathrm{C}\right)$ in general are not suitable for larval fish to live. Batty and Blaxter (1992) and Stoll and Beeck (2012) also indicated that the growth and swimming ability of larval fish was impeded by low temperature. Okazaki and Nakata (2007) suggested that the abundance of larval fish and number of species was low at low temperatures, and increased with an increase in temperature.

However, the CPUEs we obtained were significantly and positively correlated with SST in winter, but not in summer. One reason for this was that, in winter, the sea temperature was variable and cold, such that fish larvae increased with the increase in sea temperature. Another reason was that, in summer, the sea temperature was stable and warm $\left(22-30^{\circ} \mathrm{C}\right)$, such that temperature was not a limiting factor for larval survival. A suitable warm temperature is considered to be a critical factor affecting the survival and production of larval fish during the northeasterly monsoon season (Zenitani et al., 2009). Hence, during the southwesterly monsoon season, larval levels increased with primary production and zooplankton, but not with SST; this contrasted with the northeasterly monsoon season (Fig. 6). This suggested that the influence of SST on survival and production of larval fish decreased as the environment became warmer $\left(>25^{\circ} \mathrm{C}\right)$.

Food sources are another key factor for larval survival after the burn-off of all nutrients in the yolk sac occurs. Generally, an abundance of phytoplankton and zooplankton in the environment indicates sufficient nutrients. Sabatini et al. (2004) inferred that increased primary production may enhance zooplankton biomass. Hsieh et al. (2010) and Chen et al. (2012) reported that zooplankton abundance is correlated with the abundance of larval fish. Hsieh et al. (2010) observed that an abundance of larval fish was positively correlated with zooplankton wet weight, and considered this to be related to the availability of food sources. The CPUEs we obtained were significantly and positively correlated with zooplankton and primary production during summer (Fig. 6).

However, the developmental stages of the larval fish collected using the ORI net with a mesh size of $330 \mu \mathrm{m}$ were predominantly the preflexion and flexion stages. The mouth development at these stages is not complete; therefore, the larvae cannot capture most of the mature zooplankton. Nonetheless, Sassa et al. (2008) and Meng (2003) suggested 
Table 5. Summaries of the several previous studies of larval assemblage together with this survey.

\begin{tabular}{|c|c|c|c|c|c|}
\hline Source & Period & Survey area & Current & $\begin{array}{l}\text { Larval abundance } \\
\text { (ind. } / 1000 \mathrm{~m}^{3} \text { ) }\end{array}$ & Larval assemblage \\
\hline Hsieh et al. (2007) & March 2005 & $\begin{array}{l}25.7-26.2^{\circ} \mathrm{N} \text { and } \\
120-122^{\circ} \mathrm{E}\end{array}$ & Kuroshio Current (KC) & $6.7-352.2$ & $\begin{array}{l}\text { Coastal assemblage } \\
\text { Transitional assem- } \\
\text { blage } \\
\text { Kuroshio edge } \\
\text { assemblage }\end{array}$ \\
\hline Okazaki and Nakata (2007) & May 2001 & $\begin{array}{l}28.5-31.2^{\circ} \mathrm{N} \text { and } \\
126.5-128.5^{\circ} \mathrm{E}\end{array}$ & $\begin{array}{l}\text { Kuroshio Current (KC) } \\
\text { Tsushima Warm Cur- } \\
\text { rent } \\
\text { (TWC) }\end{array}$ & $\begin{array}{l}\text { Daytime: } \\
202.7 \pm 202.4 \\
\text { Nighttime: } \\
311.2 \pm 165.2\end{array}$ & $\begin{array}{l}\text { Off-shelf/Kuroshio as- } \\
\text { semblage } \\
\text { Shelf-break assemblage }\end{array}$ \\
\hline Lo et al. (2010) & $\begin{array}{l}\text { February and May } \\
2003\end{array}$ & $\begin{array}{l}21.5-26^{\circ} \mathrm{N} \text { and } \\
119-123^{\circ} \mathrm{E}\end{array}$ & $\begin{array}{l}\text { China Coastal Current } \\
\text { (CCC) } \\
\text { Kuroshio Current (KC) } \\
\text { South China Sea } \\
\text { Surface Current (SC- } \\
\text { SSC) }\end{array}$ & $\begin{array}{l}\text { February: } \\
979 \pm 388 \\
\text { May: } 924 \pm 121\end{array}$ & $\begin{array}{l}\text { February: W1, W2, W3 } \\
\text { assemblage } \\
\text { May: S1, S2, S3 } \\
\text { assemblage }\end{array}$ \\
\hline Hsieh et al. (2011) & $\begin{array}{l}\text { February, June, } \\
\text { August, and } \\
\text { November } 2004\end{array}$ & $\begin{array}{l}26^{\circ} \mathrm{N} \text { and } \\
121-123^{\circ} \mathrm{E}\end{array}$ & $\begin{array}{l}\text { China Coastal Current } \\
\text { Kuroshio Current (KC) } \\
\text { South China Sea } \\
\text { Surface Current }\end{array}$ & $\begin{array}{l}\text { February: } \\
1300 \pm 1027 \\
\text { June: } 1130 \pm 614 \\
\text { August: } \\
1130 \pm 289 \\
\text { November: } \\
377 \pm 167\end{array}$ & $\begin{array}{l}\text { SCSSC group } \\
\text { CCC group } \\
\text { KC group } \\
\text { MIX group }\end{array}$ \\
\hline Su et al. (2011) & $\begin{array}{l}\text { February and } \\
\text { August } 2004\end{array}$ & $\begin{array}{l}22-26^{\circ} \mathrm{N} \text { and } \\
121-123^{\circ} \mathrm{E}\end{array}$ & $\begin{array}{l}\text { China Coastal Current } \\
\text { Kuroshio Current }\end{array}$ & $441 \pm 141$ & $\begin{array}{l}\text { Summer shelf } \\
\text { assemblage } \\
\text { Winter-summer shelf } \\
\text { assemblage } \\
\text { Winter-summer } \\
\text { Kuroshio assemblage } \\
\text { Winter shelf and } \\
\text { summer Kuroshio } \\
\text { assemblage }\end{array}$ \\
\hline Chen et al. (2012) & June 2009 & $\begin{array}{l}25.1-26.2^{\circ} \mathrm{N} \text { and } \\
120-123^{\circ} \mathrm{E}\end{array}$ & Kuroshio Current & Total: 238.29 & $\begin{array}{l}\text { Coastal group } \\
\text { Shelf group } \\
\text { Mixed shelf group } \\
\text { Kuroshio group }\end{array}$ \\
\hline Hsieh et al. (2012) & $\begin{array}{l}\text { February } 2003 \text { to } \\
\text { November } 2004\end{array}$ & $\begin{array}{l}21.5-26^{\circ} \mathrm{N} \text { and } \\
119-121.5^{\circ} \mathrm{E}\end{array}$ & $\begin{array}{l}\text { China Coastal Current } \\
\text { Kuroshio Current } \\
\text { South China Sea Sur- } \\
\text { face Current }\end{array}$ & $949 \pm 186$ & $\begin{array}{l}\text { Cold-period } \\
\text { northern Taiwan Strait } \\
\text { assemblage } \\
\text { Southern Taiwan Strait } \\
\text { assemblage } \\
\text { Warm-period } \\
\text { northern Taiwan Strait } \\
\text { assemblage }\end{array}$ \\
\hline This study & $\begin{array}{l}\text { January and } \\
\text { July } 2008\end{array}$ & $\begin{array}{l}25-32^{\circ} \mathrm{N} \text { and } \\
120-127^{\circ} \mathrm{E}\end{array}$ & $\begin{array}{l}\text { China Coastal Current } \\
\text { Kuroshio Current } \\
\text { Taiwan Strait Current } \\
\text { (TSC) }\end{array}$ & $\begin{array}{l}\text { January: } 2288 \\
\text { July: } 13246\end{array}$ & $\begin{array}{l}\text { Inshore assemblage } \\
\text { Offshore assemblage } \\
\text { Summer coastal } \\
\text { assemblage }\end{array}$ \\
\hline
\end{tabular}

that copepods, together with their eggs and nauplii, comprise the main prey of larval fish, and that prey size increased with growth (Sassa et al., 2008; Tanabe, 2001). The prey of larvae do not belong to specific species, and the prey size rate shifts with larval growth. Therefore, the stomach content of larvae is primarily small-sized copepod nauplii, which fit inside the larvae's mouths. The mouth widths of larval fish must match the prey sizes for predation (Cunha and Planas, 

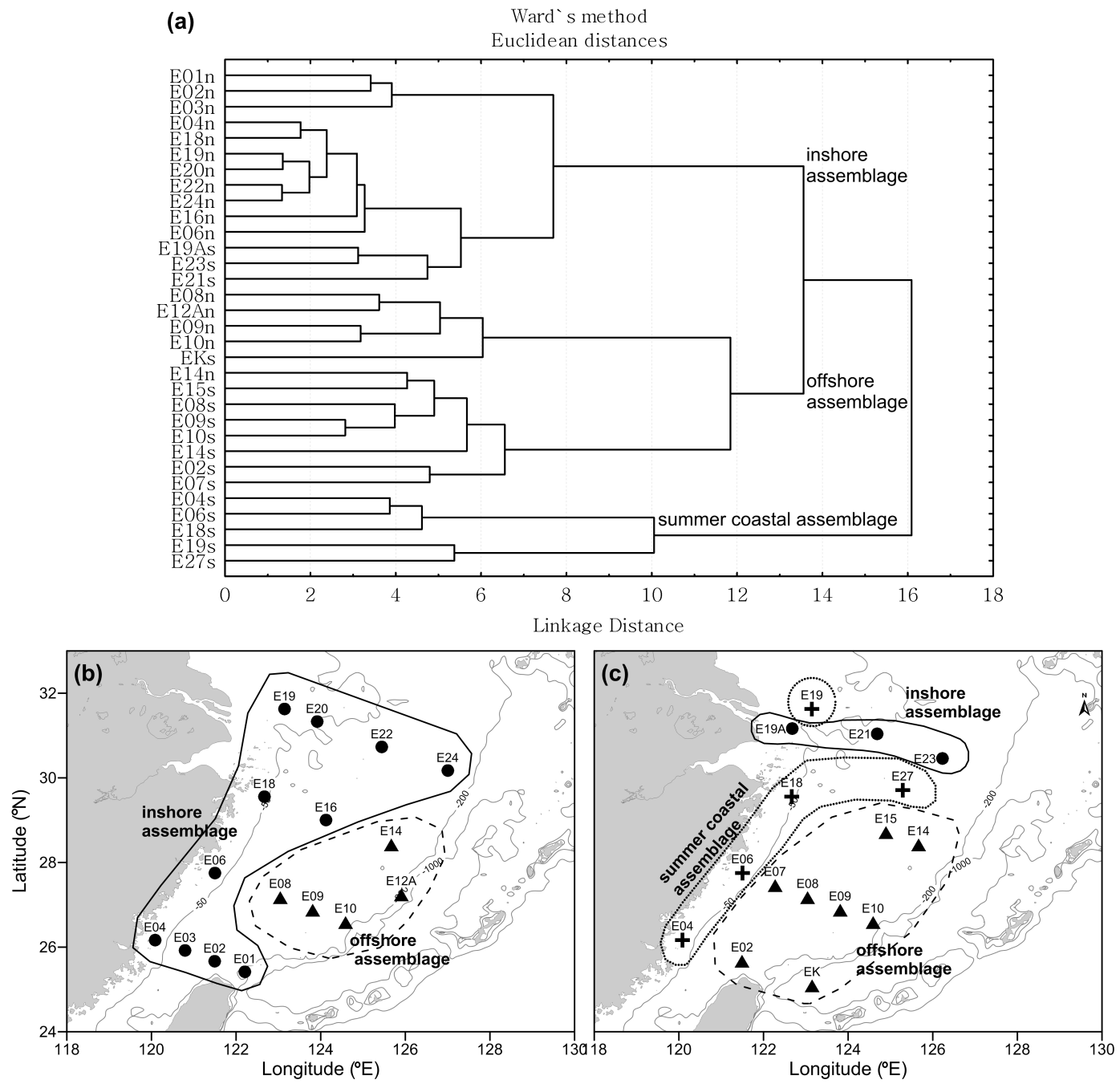

Fig. 8. The dendrogram of species composition similarity among stations ( $\mathrm{E} ; n$, in the northeasterly monsoon season; $\mathrm{s}$, in the southwesterly monsoon season) by Ward's linkage cluster analysis (a) and its geographic locations of the larval fish assemblages in the northeasterly monsoon season (b) and the southwesterly monsoon season (c) (solids circles, inshore assemblage; solid triangles, offshore assemblage; crosses, summer coastal assemblage).

1999). More than $95 \%$ of larvae are capable of capturing small-sized copepod nauplii (less than $57 \%$ of the width of a larval mouth) (Hunter and Kimbrell, 1980). Therefore, numerous studies have demonstrated that copepod nauplii could be a major food source for larval fish.

In addition, Hsieh et al. (2002) hypothesized that the abundance of fish larvae is positively related to that of copepods, but the interactions between primary productivity and copepods remain undetermined. The role of primary production and its relative importance in the diet of larval fish and copepod remains ambiguous. However, copepod abundance was positively correlated with chlorophyll a, which partially reflects primary production, and copepod egg production was enhanced by chlorophyll a (Sun et al., 2008). Primary production is also the biomass index of food availability for fish
(Chen et al., 2004); this suggests that the production and survival of larval fish is influenced by the feasibility of primary production during the southwesterly monsoon season. Therefore, primary production and zooplankton influenced and increased the wet weight and nauplii production of copepods, and vice versa.

\subsection{Larval fish assemblages in relation to oceanic currents}

Many biological features, such as trophic level, lifestyle, and migration, do not noticeably differ among larval stages and species. Fish larvae are pelagic plankton, in contrast to adult fish, which have various ecological roles (Leis, 2006). Therefore, ecological features were not the main reason for group structures. Table 5 is a summary obtained from sev- 


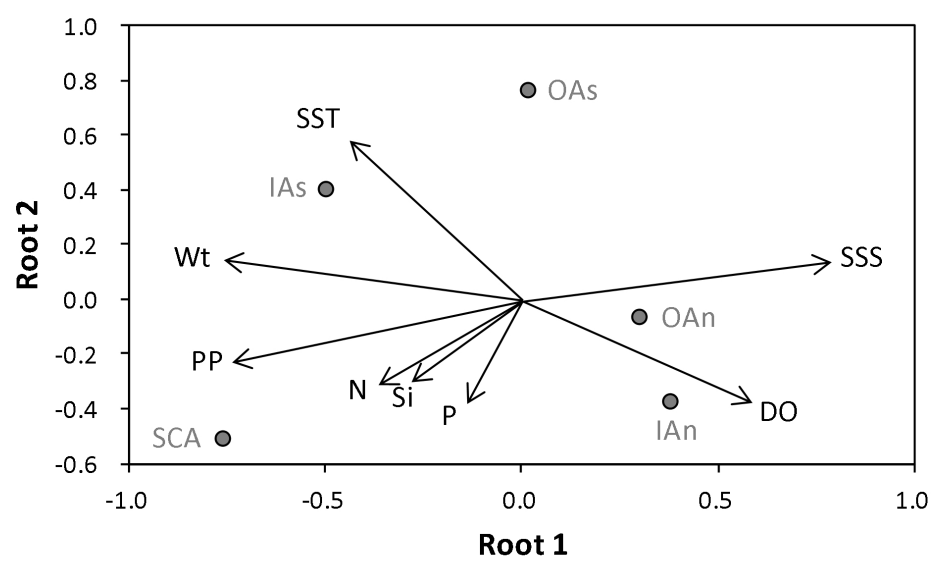

SST: sea surface Temp.
SSS: sea surface Sal.
DO: bottom $\mathrm{DO}$
$\mathrm{N}$ : surface $\mathrm{NO}_{3}$
P: surface $\mathrm{PO}_{4}$
Si: surface $\mathrm{SiO}_{3}$
PP: primary production
Wt: zooplankton $\mathrm{Wt}\left(\mathrm{g} / 1000 \mathrm{~m}^{3}\right)$
IAn: Inshore assemblage (NE)
IAs: Inshore assemblage (SW)
OAn: Offshore assemblage (NE)
OAs: Offshore assemblage (SW)
SCA: Summer coastal assemblage

Fig. 9. Ordination diagram of canonical correlation analysis (CCA) showing the relationships between hydrographic factors and abundance of assemblages.

eral studies of larval assemblage, which agree with this study. According to previous studies, larval assemblages depend on the current, particularly on the China Coastal Current and the Kuroshio Current. In this study, there were three larval fish assemblages (inshore assemblage, offshore assemblage, and summer coastal assemblage) in the ECS. Nevertheless, our results showed that the abundance of the larvae at each of the assemblages differed significantly between the two monsoon seasons. The summer coastal assemblage had the highest average CPUE (approximately 2,061 ind./1000 $\mathrm{m}^{3}$ ), approximately 12 times higher than that of the inshore assemblage, and seven times higher than that of the offshore assemblage. Moreover, spatial distribution and species composition among the three assemblages also differed significantly, which could be explained by differences in the food supply.

In previous studies, larval assemblage could be divided into two categories, a cold/warm period group and a Coastal/Kuroshio group. Our results, spanning summer and winter, included these groups. During the northeasterly monsoon season, the offshore assemblage occupied a few shelf areas at latitudes from $26^{\circ}-28^{\circ} \mathrm{N}$, whereas the inshore assemblage occupied the southern area of the ECS. This inshore assemblage receded toward the Yangtze River estuary and bank during the southwesterly monsoon season. Hsieh et al. (2011) proposed that the China Coastal Current group originated in the coastal waters of mainland China, when the northeasterly monsoon predominated, and the Kuroshio group originated in the offshore Kuroshio waters year-round. This phenomenon could also explain the relationship between inshore assemblage and sea temperature (Fig. 9). Scorpaenid larvae were dominant in inshore assemblages in both monsoon seasons. Wu (2000) reported that their optimal temperature range was $10-14^{\circ} \mathrm{C}$, which corresponded to the temperature $\left(<19^{\circ} \mathrm{C}\right)$ and salinity $(<33 \mathrm{psu})$ of the southward China Coastal Current (Jan et al., 1998; Chen and
Wang, 2006). In addition, adult scorpaenids prefer to live in shallow near-shore waters with rocky bottoms, which belong to the settled-habitat type (Okiyama, 1988); thus, adult scorpaenids spend their entire lives in their spawning grounds.

The spatial distributions of the offshore assemblage stations were observed to be stable in the shelf waters. However, the two dominant species were Valamugil spp. and $S$. gracilis during the northeasterly monsoon season, but, during the southwesterly monsoon season, the two dominant species became T. myops and Auxis larvae. Among them, Valamugil larvae were widely distributed in the ECS and Taiwan Strait, and mostly spawn in winter (Table 3); however, their taxonomy and ecology remain unclear (Durand et al., 2012). The spawning period of T. myops was from February to October (spring to autumn, Table 3), which corresponds to a warm sea-temperature period (Sadovy and Cornish, 2000). Thus, $T$. myops and Auxis larvae were abundant taxa in the warm Taiwan Strait Current (Hsieh et al., 2012), whereas S. gracilis were reported to be the dominant species in the Kuroshio (Hsieh et al., 2011). Hsieh et al. (2011) reported that S. gracilis and Auxis larvae were abundant in the Kuroshio group and transitional group (MIXG). Chen et al. (2012) also reported that Auxis larvae were in the transitional and offshore area. As shown in Fig. 7a, S. gracilis prefer warm and saline water. Nakabo (2002) indicated that this adult species mainly inhabits deep oceanic waters, whereas its larvae are pelagic, abundant in the Kuroshio Current and offshore waters. In general, larvae are pelagic plankton, sensitive to environmental changes (Ohshimo et al., 2012), and their survival depends on the availability of food and suitable temperature. Moreover, Parmesan and Yohe (2003) also indicated that the current context of marked environmental changes may affect the species distributions, natural resources, and biodiversity. This suggested that the change in the dominant species in the ECS between the two monsoon seasons might be caused 
by the northward intrusion of the Taiwan Strait Current and Kuroshio Current during the southwesterly monsoon season.

The summer coastal assemblage was the highest CPUE among the three assemblages. It was observed in the coastal waters and the Yangtze River estuary and along its bank. Su et al. (2011) proposed that seasonal turbulence enhances biological production, potentially influencing the growth and survival of larvae. Gong et al. (2011) also reported that the Yangtze River floods enhanced the coastal ocean phytoplankton biomass, potentially enhancing fish production. Therefore, the summer coastal assemblage was well-received by the influent of the Yangtze River flood, and negatively correlated with sea surface salinity (Fig. 9). E. japonicus was the third dominant species in this assemblage. It was distributed mainly at the Yangtze River estuary and the south side of the river bank; this finding is in agreement with the study by Iseki and Kiyomoto (1997), who stated that the estuary is this species' major spawning ground. Gobiid type 2 and Saurida larvae were the two most dominant species of the assemblage. Although the gobiid type 2 occurred widely in the coastal waters of the ECS, the taxonomy and phylogeny of Gobiidae are not well established, and morphological characters useful for species diagnosis of the larvae are insufficient, resulting in a constraint for the identification of the species. It is difficult to identify larval fish on the species level (Thacker and Roje, 2011; Ko et al., 2013). To solve this problem, using bio-technique methodologies has been suggested (Spies et al., 2006; Ko et al., 2013).

It may be concluded that the abundance and spatialtemporal distribution of the larval fish assemblage in the continental shelf of the ECS were related to the SST during the northeasterly monsoon season, but to food availability during the southwesterly monsoon season. There were three larval fish assemblages (inshore, offshore, and summer coastal). The composition and distribution of species in the assemblages differed between the two monsoon seasons; this resulted from changes in the oceanic currents and hydrographic conditions of the two seasons.

Acknowledgements. This research was supported in part by the National Science Council of Taiwan (100-2611-M-019-005) and the Center of Excellence for the Oceans, National Taiwan Ocean University. Our gratitude goes to the LORECS Research Team, who provided assistance in the field work and hydrographic data for the study.

Edited by: T. Kobari

\section{References}

Batty, R. S. and Blaxter, J. H. S.: The effect of temperature on the burst swimming performance of fish larvae, J. Exp. Biol., 170, 187-201, 1992.
Chang, P. H. and Isobe, A.: A numerical study on the Changjiang diluted water in the Yellow and East China Seas, J. Geophys. Res.-Oceans, 108, 1-17, 2003.

Chang, Y., Lee, M. A., Shimada, T., Sakaida, F., Kawamura, H., Chan, J. W., and Lu, H. J.: Wintertime high-resolution features of sea surface temperature and chlorophyll $a$ fields associated with oceanic fronts in the southern East China Sea, International Journal of Remote Sensing, 29, 6249-6261, 2008.

Chen, C. C., Shiah, F. K., Chiang, K. P., Gong, G. C., and Kemp, W. M.: Effects of the Changjiang (Yangtze) River discharge on planktonic community respiration in the East China Sea, J. Geophys. Res.-Oceans, 114, C03005, doi:10.1029/2008jc004891, 2009.

Chen, T. A. and Wang, S. L.: A salinity front in the southern East China Sea separating the Chinese coastal and Taiwan Strait waters from Kuroshio waters, Cont. Shelf Res., 26, 1636-1653, 2006.

Chen, W. Y., Wang, Y. C., and Lee, M. A.: Early-summer ichthyoplankton biodiversity associated with oceanic factors on the continental shelf of the southern East China Sea, J. Mar. Sci. Tech., 20, 698-706, 2012.

Chen, Y. L. L., Chen, H. Y., Gong, G. C., Lin, Y. H., Jan, S., and Takahashi, M.: Phytoplankton production during a summer coastal upwelling in the East China Sea, Cont. Shelf Res., 24, 1321-1338, 2004.

Cornillon, P., Adams, J., Blumenthal, M. B., Chassignet, E., Davis, E., Hankin, S., Kinter, J., Mendelssohn, R., Potemra, J. T., Srinivasan, A., and Sirott, J.: Nvods and the development of OPeNDAP, Oceanography, 22, 116-127, 2009.

Cunha, I. and Planas, M.: Optimal prey size for early turbot larvae (Scophthalmus maximus L.) based on mouth and ingested prey size, Aquaculture, 175, 103-110, 1999.

DiBacco, C., Sutton, D., and McConnico, L.: Vertical migration behavior and horizontal distribution of brachyuran larvae in a lowinflow estuary: implications for bay-ocean exchange, Mar. Ecol. Prog. Ser., 217, 191-206, 2001.

Durand, J. D., Shen, K. N., Chen, W. J., Jamandre, B. W., Blel, H., Diop, K., Nirchio, M., de Leon, F. J. G., Whitfield, A. K., Chang, C. W., and Borsa, P.: Systematics of the grey mullets (Teleostei: Mugiliformes: Mugilidae): Molecular phylogenetic evidence challenges two centuries of morphology-based taxonomy, Mol. Phylogenet. Evol., 64, 73-92, 2012.

Gong, G. C., Chen, Y.L. L., and Liu, K. K.: Chemical hydrography and chlorophyll a distribution in the East China Sea in summer: Implications in nutrient dynamics, Cont. Shelf Res., 16, 15611590, 1996.

Gong, G. C., Wen, Y. H., Wang, B. W., and Liu, G. J.: Seasonal variation of chlorophyll a concentration, primary production and environmental conditions in the subtropical East China Sea, DeepSea Res. Part II-Top. Stud. Oceanogr., 50, 1219-1236, 2003.

Gong, G. C., Hung, C. C., and Chang, J.: Reply to comment by Jinchun Yuan et al. on "Reduction of primary production and changing of nutrient ratio in the East China Sea: Effect of the Three Gorges Dam?", Geophys. Res. Lett., 34, 4, L14610, doi:10.1029/2007g1029633, 2007.

Gong, G. C., Liu, K. K., Chiang, K. P., Hsiung, T. M., Chang, J., Chen, C. C., Hung, C. C., Chou, W. C., Chung, C. C., Chen, H. Y., Shiah, F. K., Tsai, A. Y., Hsieh, C. H., Shiao, J. C., Tseng, C. M., Hsu, S. C., Lee, H. J., Lee, M. A., Lin, II, and Tsai, F. 
J.: Yangtze River floods enhance coastal ocean phytoplankton biomass and potential fish production, Geophys. Res. Lett., 38, L13603, doi:10.1029/2011g1047519, 2011.

Hernandez, F. J., Powers, S. P., and Graham, W. M.: Seasonal variability in ichthyoplankton abundance and assemblage composition in the northern Gulf of Mexico off Alabama, Fishery Bulletin, 108, 193-207, 2010.

Hsieh, C. H. and Chiu, T. S. : Summer spatial distribution of copepods and fish larvae in relation to hydrography in the northern Taiwan Strait. Zool. Studies, 41, 85-98, 2002.

Hsieh, F. J., Lee, M. A., Pan, J. Y., Wang, Y. T., Lan, K. W., and Lan, Y. C.: Winter distribution and composition of ichthyoplankton associated with thermal front on the continental shelf of the southern East China Sea, J. Fish. Soc. Taiwan, 34, 69-85, 2007.

Hsieh, H. Y., Lo, W. T., Liu, D. C., and Su, W. C.: Influence of hydrographic features on larval fish distribution during the southwesterly monsoon in the waters of Taiwan, western North Pacific Ocean, J. Fish Biol., 76, 2521-2539, 2010.

Hsieh, H. Y., Lo, W. T., Wu,L. J., Liu, D. C., and Su, W. C.: Monsoon-driven succession of the larval fish assemblage in the East China Sea shelf waters off northern Taiwan, J. Oceanogr., 67, 159-172, 2011.

Hsieh, H. Y., Lo, W. T., Wu, L. J., and Liu, D. C.: Larval fish assemblages in the Taiwan Strait, western North Pacific: linking with monsoon-driven mesoscale current system, Fish Oceanogr., 21, 125-147, 2012.

Hunter, J. R. and Kimbrell, C. A.: Early life history of Pacific mackerel, Scomber japonicus, Fishery Bulletin, 78, 89-101, 1980.

Iseki, K. and Kiyomoto, Y.: Distribution and settling of Japanese anchovy (Engraulis japonicus) eggs at the spawning ground off Changjiang River in the East China Sea, Fish Oceanogr., 6, 205210, 1997.

Isobe, A.: Recent advances in ocean-circulation research on the Yellow Sea and East China Sea shelves, J. Oceanogr., 64, 569-584, 2008.

Jan, S., Chern, C. S., and Wang, J.: A numerical study of currents in the Taiwan strait during winter, Terr. Atmos. Ocean. Sci., 9, 615-632, 1998.

Katoh, O., Morinaga, K., and Nakagawa, N.: Current distributions in the southern East China Sea in summer, J. Geophys. Res.Oceans, 105, 8565-8573, 2000.

Ko, H.L., Wang, Y. T., Chiu, T. S., Lee, M. A., Leu, M. Y., Chang, K. Z., Chen, W. Y., and Shao, K. T.: Evaluating the accuracy of morphological identification of larval fishes by applying DNA barcoding, PLoS ONE, 8, e53451, doi:10.1371/journal.pone.0053451, 2013.

Lee, M. A., Chang, Y., Sakaida, F., Kawamura, H., Cheng, C. H., Chan, J. W., and Huang, I.: Validation of satellite-derived sea surface temperatures for waters around Taiwan, Terr. Atmos. Ocean. Sci., 16, 1189-1204, 2005.

Leis, J. M.: Are larvae of demersal fishes plankton or nekton?, in: Advances in Marine Biology, 51, 57-141, 2006.

Leis, J. M. and Carson-Ewart, B. M.: The larvae of Indo-Pacific coastal fishes: An identification guide to marine fish larvae, Leiden press, Boston, 850 pp., 2000.

Liang, D. and Uye, S.: Population dynamics and production of the planktonic copepods in a eutrophic ilet of the inland sea of Japan IV. Pseudodiaptomus marinus, the egg-carrying calanoid, Mar. Bio., 128, 415-421, 1997.
Lo, W. T., Hsieh, H. Y., Wu, L. J., Jian, H. B., Liu, D. C., and Su, W. C.: Comparison of larval fish assemblages between during and after northeasterly monsoon in the waters around Taiwan, western North Pacific, J. Plankton Res., 32, 1079-1095, 2010.

Meekan, M. G., Carleton, J. H., McKinnon, A. D., Flynn, K., and Furnas, M.: What determines the growth of tropical reef fish larvae in the plankton: Food or temperature?, Mar. Ecol. Prog. Ser., 256, 193-204, 2003.

Meng, T. X.: Studies on the feeding of anchovy (Engraulis japonicus) at different life stages on zooplankton in the Middle and Southern Waters of the Yellow Sea, Mari. Fish. Res., 24, 1-9, 2003.

Nakabo, T.: Fishes of Japan with Pictorial Keys to the Species, in, edited by: Nakabo, T., Tokyo: Tokai University Press, 1749, 306310, 2002.

Ohshimo, S., Yasuda, T., Tanaka, H., and Sassa, C.: Biomass fluctuation of two dominant lanternfish Diaphus garmani and D. chrysorhynchus with environmental changes in the East China Sea, Fish. Sci., 78, 33-39, 2012.

Okazaki, Y. and Nakata, H.: Effect of the mesoscale hydrographic features on larval fish distribution across the shelf break of East China Sea, Cont. Shelf Res., 27, 1616-1628, 2007.

Okazaki, Y., Nakata, H., and Kimura, S.: Effects of frontal eddies on the distribution and food availability of anchovy larvae in the Kuroshio Extension, Mar. Freshwater Res., 53, 403-410, 2002.

Okiyama, M.: An atlas of the early stage fishes in Japan, Tokai University Press, 1154, 777-810, 1988.

Parmesan, C. and Yohe, G.: A globally coherent fingerprint of climate change impacts across natural systems. Nature, 421, 37-42, 2003.

Queiroga, H., Costlow, J. D., and Moreira, M. H.: Vertical migration of the crab Carcinus maenas first zoea in an estuary: Implications for tidal stream transport, Mar. Ecol. Prog. Ser., 149, 121-132, 1997.

Sabatini, M., Reta, R., and Matano R.: Circulation and zooplankton biomass distribution over the southern Patagonian shelf during late summer, Cont. Shelf Res., 24, 1359-1373, 2004.

Sadovy, Y. and Cornish, A.S.: Reef fishes of Hong Kong. Hong Kong University Press, Hong Kong, 321, 42-43, 2000.

Sassa, C., Konishi, Y., and Mori, K.: Distribution of jack mackerel (Trachurus japonicus) larvae and juveniles in the East China Sea, with special reference to the larval transport by the Kuroshio Current, Fish Oceanogr., 15, 508-518, 2006.

Sassa, C., Tsukamoto, Y., and Konishi, Y.: Diet composition and feeding habits of Trachurus japonicus and Scomber spp. larvae in the shelf break region of the East China Sea, Bull. Mar. Sci., 82, 137-153, 2008.

Spies, I. B., Gaichas, S., Stevenson, D. E., Orr, J. W., and Canino, M. F.: DNA-based identification of Alaska skates (Amblyraja, Bathyraja and Raja : Rajidae) using cytochrome c oxidase subunit I (coI) variation, J. Fish Biol., 69, 283-292, 2006.

Stoll, S. and Beeck, P.: Larval fish in troubled waters - is the behavioural response of larval fish to hydrodynamic impacts active or passive?, Can. J. Fish. Aquat. Sci., 69, 1576-1584, 2012.

Su, W. C., Lo, W. T., Liu, D. C., Wu, L. J., and Hsieh, H. Y.: Larval fish assemblages in the Kuroshio waters east of Taiwan during two distinct monsoon seasons, Bull. Mar. Sci., 87, 13-29, 2011.

Sun, X. H., Sun, S., Li, C. L., and Zhang, G. T.: Seasonal and spatial variation in abundance and egg production of Paracalanus 
parvus (Copepoda: Calanoida) in/out Jiaozhou Bay, China, Estusr. Coast. Shelf Sci., 79, 637-643, 2008.

Tanabe, T.: Feeding habits of skipjack tuna Katsuwonus pelamis and other tuna Thunnus spp. juveniles in the tropical western Pacific, Fish. Sci., 67, 563-570, 2001.

ter Braak, C. J. F.: Canonical community ordination. Part I: Basic theory and linear methods, Ecoscience, 1, 127-140, 1994.

Thacker, C. E. and Roje, D. M.: Phylogeny of Gobiidae and identification of gobiid lineages, Systematics and Biodiversity, 9, 329347, 2011.

Vargas, C. A. and Castro, L. R.: Spawning of the chilean hake (Merluccius gayi) in the upwelling system off Talcahuano in relation to oceanographic features, Scientia Marina, 65, 101-110, 2001.

Wu, C. W.: The effect of several environmental factors on the survival rate of Sebasticus marmoratus larvae, J. Zhejiang Ocean University, 19, 12-16, 2000.
Yang, D. Z., Yin, B. S., Liu, Z.L., and Feng, X. R.: Numerical study of the ocean circulation on the East China Sea shelf and a Kuroshio bottom branch northeast of Taiwan in summer, J. Geophys. Res.-Oceans, 116, C05015, doi:10.1029/2010jc006777, 2011.

Yang, D. Z., Yin, B. S., Liu, Z.L., Bai, T., Qi, J. F., and Chen, H. Y.: Numerical study on the pattern and origins of Kuroshio branches in the bottom water of southern East China Sea in summer, J. Geophys. Res.-Oceans, 117, C02014, doi:10.1029/2011jc007528, 2012.

Yannicelli, B., Castro, L. R., Valle-Levinson, A., Atkinson, L., and Figueroa, D.: Vertical distribution of decapod larvae in the entrance of an equatorward facing bay of central Chile: implications for transport, J. Plankton Res., 28, 19-37, 2006.

Zenitani, H., Kono, N., Tsukamoto, Y., and Masuda, R.: Effects of temperature, food availability, and body size on daily growth rate of Japanese anchovy Engraulis japonicus larvae in Hiuchi-nada, Fish. Sci., 75, 1177-1188, 2009. 